\title{
TRANSLATING ENGLISH NON-HUMAN SUBJECTS IN AGENTIVE CONTEXTS: A CLOSER LOOK AT DUTCH
}

\author{
STEVEN DOMS, ${ }^{1}$ BERNARD DE CLERCK $^{2}$ \\ ${ }^{1}$ Department of Linguistics, French Section, \\ Blandijnberg 2, B-9000 Gent, Belgium, Phone: +32 92644045 \\ E-mail: steven.doms@ugent.be \\ ${ }^{2}$ Ghent University, InterComm, Department of Translation, Interpreting and Communication, \\ Groot-Brittanniëlaan 45, B-9000 Gent, Belgium, Phone +32 93311 930, \\ E-mail: bernard.declerck@ugent.be
}

\begin{abstract}
While subjects of transitive action verbs in English and Dutch are typically realized as human agents (see Comrie 1989), both languages also feature instances of nonhuman agents in subject position. However, Vandepitte and Hartsuiker (2011) have shown that there are fewer options in Dutch and that translation issues present themselves in cases where both languages do not overlap. This paper wants to document overlap and differences in terms of non-prototypical subject realization by focussing on the strategies that are used in Dutch translations of six actions verbs (give, demonstrate, show, suggest, offer and tell) in combination with non-human subjects. Results reveal that a fair share of non-human subjects are also translated as such in the target language. Other strategies include occasional humanization of the non-human source text subjects, reduction of valency patterns with reduced agentivity vis-à-vis the English source-text sentences and shifts in the mapping of semantic roles onto syntactic functions.
\end{abstract}

Keywords: contrastive research, translation, non-human agent, argument structure

\section{NON-HUMAN AGENTS IN SUBJECT POSITION}

Prototypically, traditional approaches to the semantic description of verbal arguments (see Fillmore 1968) assign a special participant role to each argument in relation to the verb, each of which have typical - though not exclusive - matches with grammatical functions. The three participants of English action verbs such as to give, to show and to tell, for instance, can be identified syntactically as the Subject $(\mathrm{Su})$, the Direct Object (Do) and the Indirect Object (Io) and are matched to semantic roles such as the Agent (Ag), the Theme (Th) and the Recipient (Rec), as shown in (1). ${ }^{1}$ 
(1) a. This year I'm giving him Toys $R$ Us.

$\begin{array}{ll}\mathrm{Su} & \text { Io } \mathrm{Do} \\ \mathrm{Ag} & \mathrm{Rec} \mathrm{Th}\end{array}$

b. She showed me her shoes.

$\begin{array}{lll}\mathrm{Su} & \mathrm{Io} & \mathrm{Do} \\ \mathrm{Ag} & \mathrm{Rec} & \mathrm{Th} \\ \text { I told her } & \text { I played the cello. } \\ \mathrm{Su} & \mathrm{Io} & \mathrm{Do} \\ \mathrm{Ag} & \mathrm{Rec} & \mathrm{Th}\end{array}$

The number of participants can also be reduced, despite the presence of typically trivalent or ditransitive verbs, as in (2), where the recipient is no longer present, see also Section 4 for similar attestations in translation. Crosslinguistically, languages show similar preferences for the grammatical subject of a sentence typically taking the semantic role of Agent (I pinched him) or related animate semantic roles, e.g. Experiencer (I felt a pinch) and Recipient ( $I$ was given a warning), whereas the object typically carries the role of Patient or Theme (Comrie 1989:107). Similar patterns are attested in Dutch, which normally do not present translation issues, as shown in the Dutch translations in (2).

(2) a. You can give a good set of ground rules.

a'. Jij kan een degelijke set basisregels geven.

b. They showed a video they had brought with them.

b'. Ze toonden de video die ze hadden meegebracht.

c. Cheerleaders told: 'Strut your stuff but cover up.'

c'. Cheerleaders zeiden: 'Paradeer maar camoufleer.'

However, languages do differ in terms of the number of restrictions on mapping non-human/animate agents as subjects of verb phrases denoting actions. While the options are not limitless (see e.g. Master 1991), English is one of the languages that has a fairly broad range of different semantic roles that can occur in subject position, as shown in the examples below, which feature Time, Cause, Instrument and Location as semantic roles in subject position (see Saeed 2003:149ff for an overview of traditional semantic roles). Unlike prototypical subjects (and Agents for that matter), they are inanimate and lack features that are typically associated with subjects (e.g. volition, intention and sentience, see Dowty 1991). The non-idiomatic translations in the (b) examples already indicate that the Dutch verbs show more selectional restrictions than their English cognates. 
(3) a. The Fourth of July celebrates the historic date in 1776 on which the Declaration of Independence was signed and the United States was legally separated from the British.

b. *De vierde juli viert de historische datum in 1776 waarop de Onafhankelijkheidsverklaring were getekend en de Verenigde Staten officieel geplitst werd van Groot-Brittannië.

(4) a. His reckless freedom of speech procured him popularity.

b. *Zijn roekeloze vrije meningsuiting verschafte hem populariteit.

(5) a. Money doesn't buy you happiness.

b. *Geld koopt je geen geluk.

(6) a. This tent sleeps four. (Rohdenburg 1974)

b. *Deze tent slaap vier.

In such cases, translators resort to more idiomatic renderings, as exemplified in the examples in c. below, taken from the Dutch Parallel Corpus (see Section 3).

(7) a. Amendment No 18 suggests that some financial support and incentives might be given to manufacturers.

b. ?Amendement $\mathrm{Nr} 18$ suggereert/stelt voor om financiële steun en stimuleringsmaatregelen te creëren voor fabrikanten.

c. In amendement 18 wordt daarnaast voorgesteld om financiële steun en stimuleringsmaatregelen voor fabrikanten te creëren.

(lit.: 'In amendment 18 it is suggested to give some financial support and incentives to manufacturers.')

(8) a. The Blu-ray systems now offer compatibility with the existing DVD's $[\ldots]$

b. ? De Blu-ray systemen bieden compatibiliteit met bestaande DVD's $[\ldots]$

c. De Blu-ray systemen zijn compatibel met de bestaande DVD's [...] (lit.: 'The Blu-ray systems are compatible with existing DVD's...)

(9) a. But the e-mail message told him something was terribly wrong.

b. ? Maar de e-mail vertelde hem dat er iets vreselijk fout zat.

c. Maar uit de e-mail bleek dat er iets vreselijk fout zat.

(lit.: 'From the e-mail it became apparent that something was terribly wrong.')

In (7c), the source-text subject Amendment - No 18 no longer fulfills the agent role in Dutch and is realized as a locative Adverbial, indicating the source or container in a passive construction. In (8c), the agentive character of the sentence is reduced by translating the 'active' verb offer with the stative copula be. As such, the subject of the Dutch sentence is no longer an agent from a 
semantic perspective but the possessor of certain features, which is easily compatible with a non-human subject. In (9c), the agentive source-text subject is translated as a prepositional object - acting as the container of the message rather than the messenger itself - and the active verb tell has been replaced by the stative copula blijken. Note also that, on the whole, the active 'information transfer' scenario in the source text with three participants has been reduced to a stative attestation of information without an actual recipient (see Section 4 for a more elaborate discussion on argument reduction in translation).

In this paper we want to present a first exploration of the overlap and differences between both languages and devote detailed attention to translation issues and solutions by investigating the Dutch translations of 548 source-text sentences with non-human agents as subjects of six English action verbs. Section 2 discusses a number of previous studies and includes a contrastive perspective with German. Section 3 provides further information on data, data selection and data retrieval. The findings and conclusions are presented in Sections 4 and 5 .

\section{PREVIOUS STUDIES}

\subsection{Non-human Subjects in Dutch}

There are few studies that have actually addressed the issue of non-human agents from a translational English-Dutch perspective. D'haeyere's (2010) pilot study confirms potential translation issues for English non-human subjects-into Dutch. Her study, based on the attested translations of 200 English source text sentences with non-human agents revealed that close to half of the translations avoided literal translations with a non-human agent as the subject. In addition, Delsoir's (2011) perception study (involving 226 respondents) showed that in many cases informants tend to prefer translations that do not have non-human agent subjects, though no detailed account is given regarding the variables that influence degrees of tolerance. These apparent restrictions on non-human subject realization in Dutch cannot only be attested in translation 'products', they are also obvious from translation processes. In their experimental study, Vandepitte and Hartsuiker (2011) observe that source-text sentences with nonhuman agents in subject position lead to more hesitations and pauses during the translation process. They require more attention, mental effort and cause more processing time for the translator. As such, these findings are in line with Naturalness Theory (Dressler et al. 1987) which postulates a correlation between markedness and the cognitive-physiological complexity of linguistic units: marked structures require more cognitive work in order to be processed (and hence translated). 
Despite these differences, there is also a fair share of overlap between both languages. First, more than half of the translations in D'haeyere (2010) do feature non-human agent subjects. Second, not all sentences in Delsoir's study were discarded and third, while there may be more hesitations in translation processes involving non-human agent source-text subjects, Vandepitte and Hartsuiker's data do feature instances of non-human subjects.

While there are no detailed studies that explore contrastive differences between Dutch and English - other than the ones mentioned above -, there is a substantial bulk of literature covering cross-linguistic differences between English and German. In Section 2.2, a closer look will be taken at some of the (translational) studies on German on the basis of which a number of hypotheses will be formulated for German's sister language, Dutch.

\subsection{A Closer Look at German in Contrast with English and Dutch}

\subsubsection{Contrastive studies}

Contrastive descriptions of the set of semantic roles that both English and German allow in subject position are described in Dirven (1979), König and Nickel (1970), Radden and Dirven (1977, 1981), Zimmermann (1972). In a "detailed and exemplary" study (Hawkins 1986:57) based on a large corpus and a substantial number of informants, Rohdenburg (1974) compares possibilities for argument types in subject roles and observes that the subject-forming possibilities of German are in general a proper subset of those in English, since non-agentive semantic roles in German frequently resist being mapped onto subjects where this is possible in English. Similar observations are found in Hawkins $(1981,1986)$ and Callies (2006), whose analyses reveal that in English a much broader range of different semantic roles can occur in subject position, whereas German is much more restricted in that respect. Callies (2013) further shows that German learners of English show a significant underrepresentation of constructions with inanimate nouns as subjects that are preferred reporting devices in English abstracts and research articles in the humanities. What these studies underscore is that non-prototypical subjects, both from a semantic and syntactic point of view, remain difficult for advanced learners and are underrepresented in their written production, often due to avoidance strategies (Master 1991; Callies 2006, 2008, 2009; Kalocsai 2009).

The coarse-grained overview as presented in Table 1 (Helbig and Buscha 2001:559ff) also traces differences between German and English mapping of semantic roles onto grammatical functions. The brackets and modifications with 'rarely' indicate that while mapping of certain semantic roles onto subject 
position cannot be ruled out entirely, they do seem to be subject to quite a number of restrictions. For a description of the semantic roles, see Helbig and Buscha (2001).

Table 1

Semantic roles and mapping onto grammatical roles in English and German

\begin{tabular}{|c|c|c|}
\hline Semantic role & English & German \\
\hline Agentive & typically subject & $\begin{array}{l}\text { typically and more so than in English, } \\
\text { subject }\end{array}$ \\
\hline External causer & typically subject & typically subject \\
\hline Instrument & $\begin{array}{l}\text { adverbial, subject, (direct } \\
\text { object) }\end{array}$ & adverbial, (subject), (object) \\
\hline Affected & $\begin{array}{l}\text { typically direct object, } \\
\text { (indirect object), subject } \\
\text { (especially with affected- } \\
\text { centered verbs) }\end{array}$ & $\begin{array}{l}\text { typically direct object, (indirect object, } \\
\text { subject) }\end{array}$ \\
\hline Recipient & $\begin{array}{l}\text { typically indirect object, } \\
\text { (subject) }\end{array}$ & typically indirect object, (subject) \\
\hline Locative & adverbial, (subject, object) & adverbial, (rarely direct object, subject) \\
\hline Temporal & adverbial, (subject) & adverbial, (rarely subject) \\
\hline Resultant & direct object & direct object \\
\hline Attribute & complement only & complement only \\
\hline
\end{tabular}

The complexity of these restrictions can be illustrated by having a closer look at micro-level instantiations. We will briefly do so by focusing on a set of examples taken from Rohdenburg (1974) and Hawkins (1986), to which Dutch translations have been added in order to show the overlap between German and Dutch in contrast with English.

The example in (10), for instance, shows that Locatives in combination with verbs of authorization are allowed in English, but not in German and Dutch. Examples (11) and (12) show Instruments in combination with action verbs whose translations sound unidiomatic in German and Dutch. The same applies to the Patient in (13).

(10) a. This hotel forbids dogs.

b. * Dieses Hotel verbietet Hunde.

c. $*$ Dit hotel verbiedt honden.

(11) a. A few years ago a pfennig would buy two or three pins.

b. *Vor einigen Jahren kaufte ein Pfennig zwei bis drei Stecknadeln.

c. * Enkele jaren geleden kocht een pfennig nog twee tot drie pins. 
(12) a. This pan will grill 3 to 4 steaks.

b. * Diese Pfanne brat 3 dis 4 Steaks.

c. * Deze pan braadt 3 tot 4 steaks.

(13) a. My guitar broke string mid-song.

b. *Mitten im Lied (zer)riß meine Gitarre eine Saite.

c. * Mijn gitaar brak een snaar halfweg het nummer.

Contrary to what these examples seem to suggest, some of these semantic roles do indeed occur in subject position in German - as suggested by the coarsegrained overview in Table 1 - and Dutch, although in combination with different verbs, and subject to very individual preferences. Opinions of informants in Rohdenburg (1974) about Locations in combination with temporary weather conditions, for instance, varied extensively. Instances such as (14a) were ruled out by some and accepted by others, while the results also seemed to be affected by the descriptive adjectives that were used (see Rohdenburg 1974:134). In Dutch, too, instances such as (14c) cannot be entirely ruled out, though non-oblique realizations of the location as an adverbial in combination with the dummy subject het (In Portugal is het momenteel koud en regenachtig) would be more acceptable. Locations with verbs of smelling are also possible in all three languages as illustrated in $(15 \mathrm{a}, \mathrm{b}$, and c), but in combination with the verb stinken, German informants provided more translations with adverbial realizations of the location, as shown in (16b). Note in this respect that the literal Dutch translation in (16c) is perfectly acceptable.

(14) a. Portugal is currently cold and rainy.

b. ? Portugal ist zur Zeit kalt und regnerisch.

c. ? Portugal is momenteel koud en regenachtig.

(15) a. The little car smelled of leather, tobacco and scent.

b. Der kleine Wagen roch nach Leder, Tabak und Parfüm.

c. De kleine wagen rook naar leer, tabak en parfum.

(16) a. This room stinks.

b. Im diesem Zimmer stinkt es. (Rohdenburg 1974: 163)

c. Deze kamer stinkt.

There are other cases in which German and Dutch do not overlap entirely in terms of apparent restrictions. The German translation in (17b), for instance, is labelled ungrammatical in Rohdenburg (1974), but the Dutch translation is perfectly acceptable. ${ }^{2}$

(17) a. Tomorrow will be rather cold and showery in most places.

b. *Morgen verspricht meistenorts ziemlich kalt $\mathrm{zu}$ sein und Regenschauer zu geben. 
c. Morgen wordt het vrij koud and erg regenachtig op de meeste plaatsen.

However, in combination with a verb like bring, all three languages allow for the Temporal semantic role in subject position, as illustrated in (18) with a German original and English and Dutch translations.

(18) a. Was das Morgen bringen sollte, lag so unbestimmt vor ihm, daß er eigentlich nur eine große Öde sah (Adam Karrillon, Michael Hely).

b. It was so unclear what tomorrow would bring, that he only saw a big emptiness.

c. Het was zo onduidelijk wat de volgende dag zou brengen, dat hij enkel een grote leegte zag.

This also means that actual differences between German and Dutch - and English for that matter - may not be located at the general macro-level of semantic roles and how they map onto certain grammatical functions (i.e. the overview provided in Table 1), but rather that they need to be formulated in terms of differences in terms of attested frequencies on a micro-level for specific verb-subject constellations. Put differently, both Dutch and German allow for semantic roles other than that of Agent in subject position - though less so than English -, but individual realizations of these roles in combination with specific predicates may be assessed differently across both languages.

In addition, it is also worth mentioning that the gap between English on the one hand and German and Dutch on the other hand may be slightly smaller than it used to be. Callies (2010) refers to evidence of incipient changes in formfunction mappings of German verbs which may have emerged under the influence of English. Examples such as (19) and (20) seem to indicate that there is a tendency to relax selectional restrictions on German verbs in which nonagentive subjects are also attested in combination with verbs like kill and injure, also possible in English. The example in (21) shows that this also applies to Dutch.

(19) a. Der Anschlag tötete 72 Menschen [...] (Callies 2010)

b. The assault killed 72 people [...]

(20) a. Automatisch Zugtüren verletzten Reisende. (Callies 2010)

b. Automatic train doors injured travellers.

(21) a. Achtergelaten raket doodt voetballende kinderen in Irak. (De Morgen, 16/02/2009)

b. Abandoned missile kills children playing soccer in Iraq. 
Similar comments are made in König and Gast (2007:110), who claim that a growing number of attestations of these non-agentive subjects in German are "slowly creeping into journalese as a result of sloppy translations from English", having a "clearly non-idiomatic flavor". They also acknowledge that these changes may be mediated by the influence English exerts on all languages. See also Becher et al. (2009, 2010 and 2011) for a more elaborate view on (covert) translation as a case of language contact and trigger of contactinduced language change. At the same time, Callies (2010) also argues that these changes may be brought about or fuelled by language internal development, fed by functional motivations (which especially apply to press contexts). He argues that for the sake of rhetorical purposes, non-human constituents may be promoted to subject position if the actual agent is unknown or avoided. As such, pseudo-agentive NPs can be used to shift responsibility, concealing the actual course of action behind the events, as exemplified in (22) below:

(22) a. Deutsche soldaten töten bei Luftangriff afganische Zivilisten.

a'. German soldier kill Afghan civilians in airstrike.

b. Afganische Zivilisten bei (deutschen) Luftangriff getötet.

b' Afghan civilians killed by (German) airstrike.

c. Luftangriff töten afganische Zivilisten.

c'. Airstrike kills Afghan civilians.

As a final note, it should be observed that the reason for the attested differences between German and English - some of which are now becoming less pronounced due to language contact - can be ascribed to effects of the erosion of inflectional marking in English and increasing fixedness of word order (Plank 1983; Legenhausen and Rohdenburg 1995). For reasons of information structure (thematization/rhematization), English has considerably expanded the syntactic functions of the subject and direct object, both semantically and functionally (Callies 2010).

\subsubsection{Repercussions on translation}

Rohdenburg (1974) shows that different translation strategies are used in German regarding marked subjects. As a first strategy, the subject is retained but the verb is changed in order to adapt to the needs of the sentence. In (23b), for instance, fordern (demand) is used instead of 'to kill' and 'to injure', whose semantic meaning is recovered in the deverbal nouns Tote and Verletzte. In $(23 \mathrm{c})$, the verb is retained and the subject is changed (the direct object of the 
active clause becomes the subject of the passive). The former subject is usually realized as an adverbial/adjunct.

(23) a. Other serious fighting killed 5 and injured 12.

b. Weitere schwere Gefechte forderten 5 Tote und 12 Verletzte.

c. Bei weiteren schweren Gefechten wurden 5 Personen getötet und 12 verletzt.

(lit.: 'In other fights 5 people were killed and 12 injured'.)

Other examples of the second and most frequent strategy are illustrated below, based on Callies (2006):

(24) a. California grows the best oranges.

b. * Kalifornien wächst die besten Orangen.

c. In Kalifornien wachsen die besten Orangen.

(25) a. 69 million dollars bought him the election.

b. *69 Millionen Dollar kauften ihm die Wahl.

c. Mit 69 Millionen Dollar (er)kaufte er sich die Wahl.

Similar observations are made in Kast (2012), whose analysis of bidirectional German-English translations based on the CroCo corpus reveals that translators "employ diverging constructions in order to comply with the relevant grammatical rules and/or stylistic standards of the target language" (Kast 2012:154). Examples such as (26) reveal that the second translation strategy is also frequently used to circumvent non-idiomatic expressions.

(26) a. Day 2 covered new thinking in Globalization, Six Sigma and Product Services.

b. Am zweiten Tag widmete man sich dem Gedankenaustausch und neuen Ideen $\mathrm{zu}$ den Themen Globalisierung, Six Sigma und produktbezogene Dienstleistungen.

\subsection{Hypotheses for English-Dutch Translation}

In view of the previous studies, the comparative explorations, and the attested complexity at micro level, we will start from two more general hypotheses on the basis of which the data will be analyzed:

1) Dutch translations of English source texts will contain fewer nonhuman subjects as the options are more limited than in English. 
2) Translation techniques will be similar to those attested in German, i.e. with changes in verb types and adverbial realizations.

In passing, it should also be noted that in view of the marked nature of these constructions in the target language on the one hand, and attested simplification and risk avoidance strategies/tendencies in translation, on the other hand, nonhuman subjects may also be avoided in some cases, even when a literal translation is possible.

\section{METHODOLOGY AND DATA}

\subsection{Selecting the English Action Verbs}

The six action verbs under study have been selected based on observations in Callies (2013) and a pilot study that was carried out prior to the analysis of the Dutch Parallel Corpus. One of the main observations in Callies (2013) concerns the lower frequency of non-human subjects in combination with 'reporting verbs' (Hyland 1999:344) in L2 English academic writing by native speakers of German. These reporting verbs, which include communicative, mental and argumentative verbs such as show, demonstrate, confirm, suggest, examine and discuss, often occur in combination with non-animate nouns in English, in many cases expressing textual categories, such as analysis, article, book, chapter, data, example, section and study in English (see Dorgeloh and Wanner 2009; Lorés Sanz 2011; Wanner 2009 on fact-construction and paper-construction). Such combinations, typical of native English academic writing (see Master 1991; Biber et al. 1999; Biber and Conrad 2009) were attested far less frequently in L2 academic writing due to the marked nature of non-animate subject realization. Since Dutch is similar to German regarding restrictions on non-human subject realizations, some of the verbal contexts reported on in Callies (2013) were also regarded as potential areas of difficulties for EnglishDutch translation.

At the same time, existing studies do show that non-human subjects in agentive contexts cannot be excluded from the Dutch language altogether (see Section 2.1). To get a better view of frequencies and possibilities, a pilot study was carried out that was specifically aimed at tracing concentrations of nonhuman agents in subject position in Dutch. We manually filtered non-human subjects from a randomly compiled corpus of written data (comprising magazines, prospectuses and brochures) which allowed for preliminary observations regarding the combination and frequency of non-human agents with particular action verbs, on the basis of which potential overlap and differences with their English cognates could be traced. Surprisingly, non- 
human subjects were attested with a fair number of different verb types: verbs of causation (e.g. leiden tot - 'lead to'), verbs of creation (e.g. creëren 'create'), verbs of destruction (e.g. bezoedelen - 'spoil'), verbs of movement (e.g. rollen - 'roll'), psychological verbs (e.g. inspireren - 'inspire'), verbs of giving (e.g. geven - 'give'), verbs of showing (e.g. tonen - 'show'), verbs of communication (e.g. vertellen - 'tell') and a whole series of other action verbs which do not belong to one of the verb classes mentioned above, like baden ('bathe'), bepalen ('determine'), beschermen ('protect'), garanderen ('guaranty'), vervolledigen ('complete'), etc. Since attention will be paid to valency and shifts in semantic role mapping, di- and especially trivalent action verbs have been singled out for further study. To ensure sufficient data, the frequency of the English cognates of these verbs was also taken into account in the final selection of six action verbs. They include English cognates of two Dutch verbs of giving, two Dutch verbs of showing and two Dutch verbs of communication which were attested with non-human agents in subject position in the test corpus, all of which denote accomplishments: give (geven), offer (bieden), tell (vertellen), complemented with verbs that were also reported on in Callies (2013): show (tonen), demonstrate (aantonen) and suggest (suggereren). Since the Dutch cognates of the source-text verbs were found with non-human agents in subject position in the test corpus, we may expect instances of nonhuman subjects in the Dutch translations. However, in view of the restrictions in Dutch on the one hand, and lower frequencies of viable options (see D'haeyere 2010; Callies 2013) on the other, we also expect alternative translations, which allows for an analysis of the specific contexts in which such translations with non-human subjects are allowed for. The way in which these data were retrieved from the Dutch Parallel Corpus (DPC) is presented in Section 3.2.

\subsection{The Dutch Parallel Corpus}

Data were extracted from the 10-million-word Dutch Parallel Corpus (see e.g. Rura et al. 2008). Lemma-based queries for all verbs yielded a total number of 6,908 instances, which were subjected to additional filtering. First, phrasal verbs (e.g. show up), idioms or semi-formulaic expressions (e.g. give rise to, given the fact that), adjectival uses (e.g. a telling characteristic), etc. were eliminated. Second, the data have also been restricted to finite verb phrases and to NP realizations of subjects, which rules out clausal antecedents, reduced relative clauses, passives, infinitival or participial phrases and nominalizations.

The filtered data include both clause-level realizations in which the nonhuman agent is the subject of the main clause in combination with a finite action 
verb as in (27) and (28) and attestations at a lower level, i.e. as the antecedent of a relative clause, as in (29) and (30).

(27) Business tells us that recruitment needs to be made easier and more flexible at all skill levels.

(28) Altruism gives longer-lasting pleasure than a bar of chocolate.

(29) After all, there are moments in our lives that change us, that discontent us with our pasts and offer us new futures.

(30) Greengrass, meanwhile, is adapting the non-fiction book Imperial Life in the Emerald City - which tells the story of what happened behind closed doors in Baghdad's super-protected Green Zone.

The results of this filtering process are presented in Table 2, which provides an overview of attested human and non-human subjects in agentive contexts.

Table 2

Proportion of human and non-human agents in source texts

\begin{tabular}{|l|c|c|c|c|c|}
\hline & $\begin{array}{c}\text { EN human } \\
\text { subject }\end{array}$ & $\begin{array}{c}\text { EN non- } \\
\text { human } \\
\text { subject }\end{array}$ & & Total \\
\hline give & $\#$ & $\%$ & $\#$ & $\%$ & \\
\hline offer & 248 & 67,9 & 117 & 32,1 & 365 \\
\hline show & 162 & 61,4 & 102 & 38,6 & 264 \\
\hline demonstrate & 24 & 37,5 & 206 & 65,2 & 316 \\
\hline tell & 307 & 93,9 & 40 & 62,5 & 64 \\
\hline suggest & 61 & 49,2 & 20 & 6,1 & 327 \\
\hline Total & 912 & 62,5 & 63 & 50,8 & 124 \\
\hline
\end{tabular}

A number of trends can be observed from Table 2. First, close to $40 \%$ of the filtered data occurs with a non-human subject, which underscores the tolerance of the English language for non-human subjects, even in combination with action and communication verbs. Secondly, the proportion of non-human subjects varies substantially $(\mathrm{p}<0.05)$ across the selected verbs. Show, demonstrate and suggest have a higher proportion of non-human agent subjects, while give, offer and tell show a higher proportion of human agent subjects, although with considerable differences: tell clearly has more human subjects than give and offer, while the proportion of non-human subjects is significantly 
higher for show and demonstrate than it is for suggest. The next section will focus on the translation patterns attested for the entire category of non-human agent subjects, based on roughly 550 attestations. Attention will be paid to the translation of the source-text verbs and to the way the non-human subject is realized in the target language (see Section 4.1). Attention will also be paid to valency and transitivity reduction as translation techniques reducing agentivity (Section 4.2) and to alterations in semantic role mapping (Section 4.3). Section 4.4 briefly tackles issues of stylistic variation, restrictions and avoidance.

\section{DATA-ANALYSIS: DUTCH TRANSLATIONS}

\subsection{General Tendencies}

Dutch translations of English non-human subjects in agentive contexts can be subdivided into three categories: 1) translations that also have non-human subjects in agentive contexts as in $(31), 2)$ translations that have human subjects in agentive contexts as in (32) and 3) translations with human and non-human subjects that no longer feature an agentive context as in (33) (referred to as no agent in Table 3 below). In (31) both the non-human subject and the action verb tell are translated literally. In (32), the non-human subject 'histories' is turned into Dutch human historici (historians), while in (33) the active verb give is replaced by the Dutch stative verb vormen (constitute, form) and the indirect object is dropped. Note that the verb bring also occurs with a non-human subject (the new millennium) in the source text, which is turned into an adverbial (in the new millennium) in Dutch (see Section 4.3 for more examples).

(31) a. Fossilised bones can also tell scientists how the biggest dinosaurs managed to grow so big - they did not just grow continually throughout life, but experienced an adolescent growth spurt.

b. Gefossiliseerde beenderen kunnen wetenschappers ook vertellen hoe de grootste dinosaurussen erin slaagden zo groot te worden. Ze groeiden namelijk niet continu gedurende hun leven, maar kenden - zoals de mens - een puberale groeispurt.

(32) a. Indeed, the Iraqi civilian death toll since our invasion is now greater than the total number of British military fatalities in the Second World War, which came to an astounding 265,000 dead (some histories give this figure as 300,000) and 277,000 wounded.

b. In Irak zijn er sinds onze invasie van het land al meer burgers gedood dan er Britse militairen zijn omgekomen in de hele Tweede Wereldoorlog. Toen zouden er liefst 265.000 doden zijn gevallen, 
al hebben sommige historici het over 300.000 , en vielen er 277.000 gewonden te betreuren.

(33) a. The scale and nature of the outrage we witnessed in the United States last week gives us a warning of what else the new millennium might bring, so we must look pragmatically at what we need to do together.

b. De omvang en de aard van het geweld dat we vorige week in de VS gezien hebben vormen een waarschuwing voor wat ons in het nieuwe millennium misschien nog meer te wachten staat. Daarom moeten we pragmatisch kijken naar wat ons samen te doen staat.

Table 3 shows an overview of the attested proportions.

Table 3

Proportion of human and non-human agents and no agent in target translations

\begin{tabular}{|l|c|c|c|c|c|c|c|}
\hline & \multicolumn{2}{|c|}{ NL no agent } & \multicolumn{2}{c|}{ NL human agent } & \multicolumn{2}{c|}{ NL non-human } & Total \\
\hline & $\#$ & $\%$ & $\#$ & $\%$ & $\#$ & $\%$ & \\
\hline DU tr give & 32 & 27,4 & 8 & 6,8 & 77 & 65,8 & 117 \\
\hline DU tr offer & 24 & 23,5 & 1 & 1,0 & 77 & 75,5 & 102 \\
\hline DU tr show & 91 & 44,2 & 6 & 2,9 & 109 & 52,9 & 206 \\
\hline $\begin{array}{l}\text { DU tr } \\
\text { demonstrate }\end{array}$ & 17 & 42,5 & 0 & 0,0 & 23 & 57,5 & 40 \\
\hline DU tr tell & 9 & 45,0 & 1 & 5,0 & 10 & 50,0 & 20 \\
\hline DU tr suggest & 19 & 30,2 & 4 & 6,3 & 40 & 63,5 & 63 \\
\hline Total & 192 & 35,0 & 20 & 3,6 & 336 & 61,3 & 548 \\
\hline
\end{tabular}

Interestingly, the overview shows that over $60 \%$ of the source-text sentences retain the agentive context with a non-human subject. Table 4 gives a nonexhaustive overview of action verbs that have been attested with non-human agents in the Dutch translations for each of the verbs under discussion. The numbers between brackets indicate the number of attestations.

While it is indeed the case that the Dutch language is more restricted than English in terms of non-human subject realizations, as shown in Section 2.1, this overview shows that some of these observations need to be toned down: with particular action type verbs the Dutch language seems to be quite susceptible to non-human subjects. Both the preliminary pilot study, which illustrated the occurrence of non-human subjects in fairly diverse verbal contexts and the attested proportion of non-human subjects in agentive contexts in the DPC data indicate that the restrictions for Dutch are less stringent in these 
specific contexts (see also Callies 2010; Gast and König 2007 on German). The first hypothesis that was raised, i.e. that the Dutch translations would contain fewer non-human subjects is validated by the data and confirms earlier studies that acknowledge the existence of non-human subjects, but in addition to emphasizing the restrictions, the attested proportions also indicate that the marked nature of these subjects is fairly context-dependent.

Table 4

Attested action verbs with non-human subjects in Dutch translations

\begin{tabular}{|l|l|}
\hline & Action verbs as translations for English source-texts verbs with NH subjects \\
\hline DU tr give & $\begin{array}{l}\text { aanbieden (1), aantonen (1), afgeven (1), beschrijven (1), bezorgen (1), } \\
\text { bieden (8), brengen (1), geven (47), gunnen (1), leveren (2), maken (4), } \\
\text { opleveren (4), verlenen (2), vermelden (1), verschaffen (1), werken (1) }\end{array}$ \\
\hline DU tr offer & $\begin{array}{l}\text { aanbieden (2), bezorgen (1), bieden (57), brengen (2), geven (6), leveren } \\
\text { (2), maken (1), opleveren (1), presteren (1), ter beschikking stellen (1), } \\
\text { tonen (1), zorgen voor (2) }\end{array}$ \\
\hline DU tr show & $\begin{array}{l}\text { aan het licht brengen (1), aangeven (5), aantonen (42), bevestigen (2), } \\
\text { bewijzen (5), blijk geven van (2), duidelijk maken (2), geven (1), illustreren } \\
(2), \text { in kaart brengen (1), laten zien (16), leren (1), tonen (18), uitwijzen (4), } \\
\text { vertonen (1), weergeven (2), wijzen (1), wijzen op (1), zorgen voor (1) }\end{array}$ \\
\hline $\begin{array}{l}\text { DU tr } \\
\text { demonstrate }\end{array}$ & $\begin{array}{l}\text { aangeven (1), aantonen (9), bewijzen (1), blijk geven van (1), duidelijk } \\
\text { maken (1), illustreren (1), indicatie geven (1), laten zien (6), zorgen voor } \\
\text { (2) }\end{array}$ \\
\hline DU tr tell & $\begin{array}{l}\text { het relaas doen van (1), informeren (1), verduidelijken (1), vertellen (5), } \\
\text { zeggen over (1), zeggen tot (1) }\end{array}$ \\
\hline DU tr suggest & $\begin{array}{l}\text { aangeven (2), aantonen (5), doen vermoeden (2), doen vrezen (1), duiden } \\
\text { op (2), gewag maken van (1), indruk wekken (1), laten vermoeden (3), laten } \\
\text { zien (1), suggereren (7), tonen (1), uitwijzen (1), veronderstellen (1), } \\
\text { voorstellen (1), wijzen op (11) }\end{array}$ \\
\hline Total & \begin{tabular}{l}
336 \\
\hline
\end{tabular} \\
\hline
\end{tabular}

Secondly, Table 3 also shows that humanization (i.e. the non-human subject is replaced by a human one but its propositional content is retained elsewhere, as in 32) is a translation technique that is used fairly infrequently. Thirdly, on average $35 \%$ of the original agentive verb contexts have been turned into translations that lack a clear agent as in (33) above and in (34) and (35) below. In (34) the transfer situation is changed into a stative construction with copular zijn (be), and in (35) dreads no longer is an agent telling a story, but a passive container. 
(34) a. It is a powerful message that his life has given to the enlarging Europe.

b. Zijn leven was een krachtige boodschap voor de uitbreiding van Europa.

(lit.: 'His life was a powerful message for the enlargement of Europe.')

(35) a. Or do dreads tell a different story now?

b. Of hebben dreads vandaag een heel andere boodschap?

(lit.: 'Or do dreads contains a totally different message today?')

Table 5 gives a non-exhaustive overview of the attested non-agentive verbs that haven been used as translations for the English source texts. The table does not include instances of nominalizations or verbs that were attested in passive constructions.

Table 5

Attested non-agentive verbs with non-human subjects in Dutch translations

\begin{tabular}{|l|l|}
\hline & Non-agentive verbs as translations for English source-texts verbs with NH subjects \\
\hline DU tr give & $\begin{array}{l}\text { betekenen (1), hebben (3), krijgen (6), verkrijgen (1), verwerven (3), vestigen (1), vormen } \\
\text { (2), zich voelen (1), zijn (3) }\end{array}$ \\
\hline DU tr offer & hebben (5), krijgen (2), vertonen (1), vormen (1), zijn (5) \\
\hline DU tr show & $\begin{array}{l}\text { afnemen met (1), afsluiten met (1), bedragen (3), blijken uit (32), dalen met (1), de wind } \\
\text { in de zeilen hebben (1), hebben (2), kennen (2), komen (1), leiden tot (2), naar voren } \\
\text { komen (1), nominalisering (3), overtuigd zijn (1), projecteren (passief) (1), realiseren } \\
\text { (passief) (1), staan (2), stijgen met (1), te zien zijn (4), tevoorschijn komen (1), vaststellen } \\
\text { (1), zien (5), zijn (5) }\end{array}$ \\
\hline $\begin{array}{l}\text { DU tr } \\
\text { demonstrate }\end{array}$ & blijken uit (6), teken zijn (1), variëren (1), vertonen (8), zijn (1) \\
\hline DU tr tell & blijken uit (1), duidelijk worden (1), hebben (1), horen (1), staan (2), weten (2) \\
\hline $\begin{array}{l}\text { DU tr } \\
\text { suggest }\end{array}$ & blijken uit (7), klinken als (1), zich aftekenen (1), zijn (2) \\
\hline Total & 192 \\
\hline
\end{tabular}

Summing up, these general tendencies indicate that English non-human subjects in agentive contexts are also fairly frequently translated as such into Dutch. At the same time, though, 'humanization' (Strategy 2) and especially 'deagentivation' (Strategy 3) also account for a fair part of the data. This general overview, in which different options are presented for the same set of verbs, also shows that existing restrictions in Dutch are also situated at a micro-level 
and that decisions are influenced by the very specific features of the setting the subject-verb constellations occur in. In the next section, attention will be paid to strategies involving aspects of valency and transitivity that also have a bearing on agentivity and acceptability.

\subsection{Changes in Valency and Transitivity}

Whether or not the non-human agent and the action verb was retained in translation are not the only variables worth looking at. As mentioned in Section 1 , some of the translations also display a reduction in the number of arguments, despite the retention of the original non-human subject. In (36) below, for instance, the non-human subject is retained, but the verb give is translated by bieden (offer) instead of literal geven (give) and the indirect object him is also dropped.

(35) a. This compositional approach - which could be horizontal or vertical in format - gave him ample scope for inventive mark-making, and for varying and controlling his colour scheme, working almost musical variations on his theme.

b. Dit compositieschema, dat hij op een horizontaal én verticaal formaat kon toepassen, bood veel ruimte voor een inventieve penseelvoering en voor een gevarieerd en tegelijkertijd beheerst kleurenschema, resulterend in bijna muzikale variaties op zijn thema's.

Dropping the indirect object turns this event into less of a telic activity, i.e. transfer from an instigating subject agent to a recipient is no longer implied. Instead, by reducing the number of arguments (in this case the indirect object), the event in the source text as one in which a non-human subject provides a service to a third party is turned into a less agentive context in which services are made available but not transferred. Dutch, as opposed to English, seems to be less prone to feature non-human constituents in subject position that do not have the control to realize actual transfer or bring about change in other participants expressed in the sentence (see Dowty 1991; Klein and Purdue 1997 on the impact of control on subject selecting mechanisms). ${ }^{3}$ As such, the event is more stative in nature in describing features of the subject that are available for third parties to be used, but it no longer expresses the element of controllable transfer. A similar argument reduction with reduced agentivity is also attested in the example below. In (36) offer is translated as allow but you is not translated which again turns the active permissive context into one in which possibilities are made available. 
(36) a. So the home theater offers you a lot more than pure cinema excitement.

b. Het home theater laat dus veel meer toe dan puur filmplezier.

c. ? Het home theater laat $\mathrm{u}$ dus veel meer toe dan puur filmplezier.

In total, 102 (or roughly $18 \%$ ) of the Dutch translations featured instances of argument reduction. Proportionally, reduction was attested most frequently with three arguments: $34 \%$ of the original source-text sentences with three arguments were reduced to patterns with two or one argument, while only $12 \%$ of twoargument structures were reduced to monotransitive or intransitive patterns. Argument reduction mostly manifested itself in contexts with a non-agentive rendering of the source-text sentence in which semantic roles were mapped differently. Examples of this kind will be illustrated in Section 4.3.

\subsection{Changes in Semantic-syntactic Role Mapping}

One of the most frequently attested translation strategies in non-agentive contexts involved changes in the mapping of semantic roles onto grammatical functions from source to target texts. 100 out of 192 (or 52\%) of non-agentive translations featured instances where the semantic role expressed by the sourcetext non-human subject is mapped onto another syntactic function, in most cases adverbials. ${ }^{4}$ At the same time, semantic roles assumed by other syntactic functions in the source text are promoted to subject position in the target text. In many cases, this change in mapping also leads to the target subject slot being filled by a human NP. In (37) the semantic role TIME that is mapped onto the subject in the source text is turned into an adjunct in the target text op 11 september. The indirect object Recipient us is promoted to subject position we and functions as an Agent. As such, this shift in perspective no longer has a non-human subject causing the indirect object to see something, but rather a human subject that witnesses events at a specific moment. Similar situations are attested with source-text Locations or Instruments in subject position being converted into place or means/instrument adverbials. In (38) and (39) this leaflet and Amendment 18 are turned into adjuncts. Note also the argument reduction in (38) (you is not present as the indirect object of tell in the Dutch translation), as discussed in Section 4.3.

(37) a. Mr President, 11 September showed us that the world we live in is very insecure.

b. Mijnheer de Voorzitter, op 11 september hebben we gezien dat de wereld waarin wij leven zeer onveilig is. 
(lit.: 'Mr President, on 11 September, we have seen that the world we live in is very insecure.')

(38) a. This leaflet tells you how to deal with mild hypoglycaemia.

b. In deze bijsluiter staat vermeld hoe u bij een lichte hypoglykemie dient te handelen.

(lit.: 'In this leaflet it is mentioned how you must deal with a mild hypoglycaemia.')

(39) a. Amendment No 18 suggests that some support might be given to manufacturers.

b. In amendement 18 wordt voorgesteld om steun voor fabrikanten te creëren.

(lit.: 'In amendment 18 it is proposed to create support for manufacturers.')

An interesting change in perspective can also be observed in (40), where the transfer verb give is replaced by receptive krijgen (get) in the Dutch translation on the basis of which the human Recipient in the source text is now allocated to the subject position in the translation and the original subject further presentations is turned into an adverbial.

(40) a. Further presentations gave attendees a comprehensive overview of ArcelorMittal Flat Carbon Europe's market position and complete steel solutions offering, which is backed up by a global presence with benefits captured along the value chain.

b. In andere presentaties kregen de aanwezigen een uitgebreid overzicht van ArcelorMittal Flat Carbon Europe's marktpositie en ons complete assortiment aan staaloplossingen. Die worden ondersteund door onze wereldwijde aanwezigheid zodat we voor een maximale toegevoegde waarde kunnen zorgen.

(lit.: 'Attendees got a comprehensive overview [...] in other presentations.')

Summing up, the attested translation strategies listed in the sections above are very similar to the ones attested for German in English-German translations, as raised in Hypothesis 2. Non-human subjects do occur in agentive contexts, but changes in target-text verb (from action to stative verb), alteration of the sourcetext subject to a humanized subject and remapping of semantic roles indicates that there are indeed more restrictions in Dutch than in English. At a microlevel, the analysis that has been carried out so far, however, does not yet allow for a detailed overview of overlap and differences regarding combinations of specific verbs with specific non-human subjects between English, Dutch and German. There are a number of reasons for this, which will be addressed in 4.4. 


\subsection{Stylistic Variation, Restrictions or Avoidance?}

Even at a micro-level, differences in terms of possibilities for non-human agents are difficult to trace at this stage. First, similar subject-verb combinations are not always translated in the same way. The examples in (41) and (42), for instance, both feature research in combination with suggest - as typical instances of the paper-construction (Wanner 2008) - but trigger a non-agentive (41) and an agentive translation (42). This may indicate that the literal translation in (42), while possible, may actually be used less frequently (though more data is needed to corroborate this). At the same time, both examples may also illustrate stylistic variation without being symptomatic of underlying quantitative differences. The same applies to the translation of non-human study in (43) and (44), which occurs both as a non-human subject in an agentive context (44) and as an adverbial with a stative verb (43).

(41) a. Research suggests that there could be about 60 children in Glasgow who have used heroin by the age of 12 .

b. Volgens onderzoek zouden in Glasgow zestig kinderen op hun twaalfde al heroïne gebruiken. (lit.: 'According to research...')

(42) a. Dr Tallis said modern research suggested that the effects of being lovesick could be described in the latest diagnostic terms.

b. Recent onderzoek toont volgens de klinisch psycholoog aan dat de effecten van dolverliefdheid kunnen worden omschreven volgens de recentste diagnostische termen.

(43) a. A second study showed that women taught self-hypnosis reduced their need for analgesia by half, epidurals by 70 per cent, and were more than twice as likely to be satisfied with their pain management in labour compared with other women.

b. Uit een tweede studie bleek dat vrouwen die zichzelf hypnotiseerden de helft minder pijnstillers nodig hadden, 70 procent minder ruggenprikken vroegen en meer dan twee keer zo tevreden waren over de pijnbestrijding tijdens de bevalling. (lit.: 'From a second study it appear that...')

(44) a. Our study shows for the first time the entire process that goes on in our brain for life.

b. Onze studie brengt voor de allereerste keer het hele proces van hersenactiviteit in de loop van een mensenleven in kaart. (lit.: Our study maps the entire process of brain activity...) 
A closer look at the translations of study, data, results and research in combination with the verbs under study revealed that 29 out of 48 instances (or $60 \%$ ) are translated as non-human subjects in an agentive context. While this may indicate the presence of tighter restrictions in Dutch or avoidance in translation, closer analysis of these examples reveals that the absence of a literal translation does not entail that a literal translation was not possible (as shown in the examples above). Secondly, translations may be affected by concerns other than the compatibility between agentive contexts and non-human subject. In (45), for instance, the information structure and order of constituents is retained at the cost of a more literal translation of subject and verb (which would have been possible as well, though with a different sentence structure).

(45) a. But in the end it was a familiar foe - climate change - that did for our evolutionary cousins, the Neanderthals, new research suggests.

b. Maar uiteindelijk was het een bekende vijand - een klimaatverandering - die de neanderthalers de das heeft omgedaan, zo blijkt uit nieuw onderzoek.

In other words, lower attestations in translations need not imply that there are fewer options or that these lower frequencies are the result of avoidance strategies. There may simply be other variables at play that have not been explored in depth in this study. Some of these will be addressed in the suggestions for further research, following the conclusions in the next section.

\section{CONCLUSIONS AND FURTHER RESEARCH}

A number of conclusions can be drawn from this first exploration of the Dutch translation patterns for non-human subjects in combination with the action verbs give, offer, show, demonstrate, tell and suggest. First, while there are fewer attestations of non-human subjects in agentive contexts than in the English data (confirming Hypothesis 1), roughly $60 \%$ of the translations do contain nonhuman subjects in agentive contexts. Despite attested restrictions in earlier studies, the current data - and the pilot study for that matter - do emphasize that the Dutch language does not shy away from using non-human subjects in the agentive contexts expressed by these verbs. Secondly, in those contexts where the subject-predicate combinations were translated differently, substantial overlap was attested with translation strategies in German, which corroborates Hypothesis 2. The agentive nature of the context is either reduced by changing the verb into a stative predicate or by reducing the number of arguments which eliminate transfer interpretations. Finally, translations also feature changes in 
semantic-syntactic mapping which often allocates Instruments, Locations and Time to adverbial positions, while the source-text Recipient in the indirect object position is often promoted to subject position. On a more fine-grained level, substantial variation has been attested in the translation of specific subject-predicate combinations: further research is needed to explore contextspecific restrictions and cross-linguistic differences.

We see various avenues for further research. First, the data need to be examined more carefully in order to trace micro-level differences between both languages. In order to do so, one has to corroborate whether non-agentive translations can also be translated with non-human subjects in agentive contexts, which also entails research that includes interrater agreement and/or an experimental design that probes into acceptability. Since the verbs under question have different types of complementation patterns (e.g. nominal vs. sentential), we need to examine whether these have an impact on the choices that are made. Secondly, it would also be interesting to further explore GermanDutch contrasts and to lay bare possible differences between both languages (as suggested by some of the examples mentioned in Section 2.2). Thirdly, diachronic research is needed to verify if and to what extent English has also influenced Dutch regarding the use of non-human subjects (cf. Gast and König 2007 on German). Finally, the polysemous nature of the verbs under study and the meanings that are triggered by the constructions they occur in need to be studied in greater depth. While the presence of a non-human subject may indeed trigger the use non-agentive verbs in the target language, the actual choice of the target-text verb is of course also determined by the degree of semantic overlap between possible candidates.

\section{Notes}

${ }^{1}$ Note that we used Quirk et al.'s 1985 definition of theme as “a participant which does not cause the happening denoted by the verb, but is directly involved in some other way" (1985:741). See Quirk et al. (1985:740-754) for a more elaborate discussion.

${ }^{2}$ It may very well be the case that examples of this kind would be more acceptable nowadays. See also Callies (2010).

${ }^{3}$ Klein and Perdue (1997) argue that the selection of thematic roles of participants is related to the degree of control that NP referents may have over each other. They argued that the NP referent with the highest degree of control comes first, i.e. that NPs that have a higher degree of control over other NP referents - and which are thus more agent-like - appear in subject position.

${ }^{4}$ Other strategies include the use of a non-agentive verbs and the retention of the nonhuman subject as discussed in Section 4.1, omissions and passivization. 


\section{References}

Becher, V., House, J. \& Kranich, S. 2009. Convergence and Divergence of Communicative Norms through Language Contact in Translation. In: Braunmüller, K. \& House, J. (eds), Convergence and Divergence in Language Contact Situations. Amsterdam: John Benjamins, 125-151.

Becher, V., House, J. \& Kranich, S. 2010. How Translations from English Shape the Genre of Popular Scientific Writing in German. Paper presented at the workshop Language Contact through Written Discourse. Synchronic and Diachronic Perspectives, conference on Multilingual Individuals and Multilingual Societies (MIMS), Research Center on Multilingualism, Hamburg/Germany, October 6-8, 2010.

Becher, V., Höder, S. \& Kranich, S. 2011. A Tentative Typology of Translation-induced Language Change. In: Kranich, S., Becher, V. Höder, S. \& House, J. (eds) Multilingual Discourse Production. Synchronic and Diachronic Perspectives. Amsterdam: John Benjamins.

Biber, D. \& Conrad, S. 2009. Register, Genre, and Style. Cambridge: Cambridge University Press.

Biber, D., Johansson, S., Leech, G., Conrad, S. \& Finegan, E. 1999. Longman Grammar of Spoken and Written English. Harlow: Longman.

Callies, M. 2006. Why Money can't Buy you Anything in German: A Functional-typological Approach to the Mapping of Semantic Roles to Syntactic Functions in SLA. In: Arabski, J. (ed.), Cross-linguistic Influences in the Second Language Lexicon. Clevedon: Multilingual Matters. 111-129.

Callies, M. 2008. Easy to Understand but Difficult to Use? Raising Constructions and Information Packaging in the Advanced Learner Variety. In: Gilquin, G., Papp, S. \& Díez-Bedmar, M. B. (eds) Linking up Contrastive and Learner Corpus Research. Amsterdam: Rodopi. 201-226.

Callies, M. 2009. Information Highlighting in Advanced Learner English. The Syntax-Pragmatics Interface in Second Language Acquisition. Amsterdam: John Benjamins. http://www.staff.uni-mainz.de/mcallies/talks/ICLC6.2010.pdf

Callies, M. 2010. The Expansion of the Subject and the Object Function in German: Contactinduced or Language Internal Change? Paper presented at the Sixth International Contrastive Linguistics Conference (ICLC6). Berlin. 30 September - 2 October.

Callies, M. 2013. Agentivity as a Determinant of Lexico-grammatical Variation in L2 Academic Writing. International Journal of Corpus Linguistics Vol. 18. No. 3. 357-390.

Comrie, B. 1989. Language Universals and Linguistic Typology. Syntax and Morphology. Chicago: University of Chicago Press.

Delsoir, J. 2011. The Acceptability of Non-prototypical Agents with Prototypical Agent Requiring Predicates in Dutch. Unpublished MS. Gent: Hogeschool Gent.

D'haeyere, L. 2010. Non-prototypical Agents with Proto-agent Requiring Predicates: a Corpus Study of their Translation from English into Dutch. Unpublished MS. Gent: Hogeschool Gent.

Dirven, R. 1979. Kasusgrammatik und Fremdsprachenunterricht. In: Diller, H.-J. (ed.) Semantik. Trier: WVG. 41-62.

Dorgeloh, H. \& Wanner, A. 2009. Formulaic Argumentation in Scientific Discourse. In: Corrigan, R. Moravcsik, E. A. Ouali, H. \& Wheatley, K.M. (eds) Formulaic Language: Volume 2. Acquisition, Loss, Psychological Reality, and Functional Explanations. Amsterdam: John Benjamins. 523-544.

Dowty, D. 1991. Thematic Proto-roles and Argument Selection. Language Vol. 67. No. 3. 547-619. 
Dressler, W. U., Mayerthaler, W., Panagl, O. \& Wurzel, W. U. 1987. Leitmotifs in Natural Morphology. Amsterdam: John Benjamins.

Fillmore, C. 1968. The Case for Case. In: Bach, E. \& Harms, R. (eds) Universals in Linguistic Theory. New York: Holt, Rinehart \& Winston. 1-88.

Hawkins, J.A. 1981. The Semantic Diversity of Basic Grammatical Relations in English and German. Linguistische Berichte Vol. 75. 1-25.

Hawkins, J.A. 1986. A Comparative Typology of English and German: Unifying the Contrasts. Austin, London and Sydney: Croom Helm.

Helbig, G. \& Buscha, J. 2001. Deutsche Grammatik: Ein Handbuch für den Ausländerunterricht. Berlin, München: Langenscheidt.

Hyland, K. 1999. Academic Attribution. Citation and the Construction of Disciplinary Knowledge. Applied Linguistics Vol. 20. No. 3. 341-367.

Kast, M. 2012. Variation within the Grammatical Function 'subject' in English-German and German-English Translations. In: Hansen-Schirra, S., Neumann, S. \& Steiner, E. (eds) Cross-linguistic Corpora for the Study of Translations Insights from the Language Pair English-German. Berlin/Boston: De Gruyter.147-160.

Kalocsai, K. 2009. Semantically Marked English Subjects: Potential and Actual Areas of Difficulty from the Point of View of Hungarian Learners of English. Porta Linguarum Vol. 12. 55-74.

Klein, W. \& Perdue, C. 1997. The Basic Variety (Or: Couldn't Natural Languages be much Simpler?). Second Language Research Vol. 13. No. 4. 301-347.

König, E. \& Nickel, G. 1970. Transformationelle Restriktionen in der Verbalsyntax des Deutschen und Englischen. In: Moser, H. et al. (eds) Probleme der kontrastiven Grammatik. Düsseldorf: Schwann. 70-81.

König, E. \& Gast.V. 2007. Understanding English-German Contrasts. Grundlagen der Anglistik und Amerikanistik. Berlin: Erich Schmidt Verlag.

Legenhausen, L. \& Rohdenburg, G. 1995. Kontrastivierung ausgewählter Strukturen im Englischen und Deutschen. In: Ahrens, R., Bald, W-D. \& Hüllen, W. (eds) Handbuch English als Fremdsprache. Berlin: Erich Schmidt. 133-139.

Lorés Sanz, R. 2011. The Construction of the Author's Voice in Academic Writing: The Interplay of Cultural and Disciplinary Factors. Text \& Talk Vol. 31. No. 2. 173-193.

Master, P. 1991. Active Verbs with Inanimate Subjects in Scientific Prose. English for Specific Purposes Vol. 10. 15-33.

Plank, F. 1983. Transparent vs. Functional Encoding of Grammatical Relations: A Parameter for Syntactic Change and Typology. Linguistische Berichte Vol. 86. 1-13.

Quirk, R., S. Greenbaum, G. Leech, \& J. Svartvik. 1985. A Comprehensive Grammar of the English Language. Harlow: Longman.

Radden, G. and Dirven, R. 1977. Semantische Syntax des Englischen. Wiesbaden: Athenaion.

Radden, G. and Dirven, R. (eds). 1981. Kasusgrammatik und Fremdsprachendidaktik. Trier: WVT.

Rohdenburg, G. 1974. Sekundäre Subjektivierungen im Englischen und Deutschen. Vergleichende Untersuchungen zur Verb- und Adjektivsyntax. Bielefeld: Cornelsen-Velhagen \& Klasing.

Rura, L., Vandeweghe, W. \& Perez, M. M. 2008. Designing a Parallel Corpus as a Multifunctional Translator's Aid. In: Proceedings of the XVIII FIT World Congress (4-7 August, 2008, Shanghai, China) from http://www.kuleuvenkulak.be/DPC/algemeen/ src/FIT2008-rural.pdf.

Saeed, J. 2003. Semantics. Oxford: Blackwell.

Vandepitte, S. 2007. Semantic and Pragmatic Meanings in Translation. In: Vandeweghe, W., Van De Velde, M. Vandepitte, S. (eds) The Study of Language and Translation. Belgian Journal of Linguistics Vol. 21. 185-200. 
Vandepitte, S. \& Hartsuiker, R. J. 2011. Metonymic Language Use as a Student Translation Problem: Towards a Controlled Psycholinguistic Investigation. In: Alvstad, C. A., Hild, A. $\&$ Tiselius, E. (eds) Methods and Strategies of Process Research. Integrative Approaches in Translation Studies. Amsterdam/Philadelphia: John Benjamins. 67-92.

Wanner, A. 2009. Deconstructing the English Passive. Berlin: Mouton de Gruyter.

Zimmermann, R. 1972. Die Kasusgrammatik in der angewandten und kontrastiven Linguistik. IRAL Vol. 10. 167-78. 